\title{
Case Report \\ Neurotized latissimus dorsi flap: functional lower limb coverage in subacute trauma reconstruction
}

Julie Chakriya Kvann, MD¹, Stephanie Thibaudeau, MD¹, Alain Joe Azzi, MD¹, Teeanoosh Zadeh, MD MJM 2017 15(22)

\section{Abstract}

In the reconstruction of the mangled lower extremity, muscle flaps are well known for their reliable use in soft tissue coverage, however, very few reports document their functional reconstruction potential as neurotized muscle flaps.

This case illustrates that free neurotized latissimus dorsi flaps are a good option for long-term functional reconstruction in the mangled lower extremity. Our report is the first case in the literature to date describing a subacute reconstruction with a functional latissimus dorsi in lower extremity trauma.

Neurotization, latissimus dorsi, free tissue flaps, lower extremity, surgical traumatology

${ }^{1}$ Division of Plastic and Reconstructive Surgery, McGill University, Montréal, Canada.

Corresponding Author: Julie Chakriya Kvann, email julie.kvann@gmail.com.

\section{Introduction}

The mangled lower extremity can represent a complex challenge for the reconstructive surgeon. With the advancement of microsurgery, free flaps in lower limb reconstruction changed from the last step of the "reconstructive ladder" to one of the top standards of the "reconstructive elevator" (1). They are safe and reliable options for soft tissue reconstruction of the lower limb in various contexts such as high-energy trauma, chronic infection, and post oncologic resections (2). However, they are uncommon in the context of functional muscle reconstruction, especially in trauma patients, where the priority is soft tissue coverage. We 
hereby present a case of subacute neurotized latissimus dorsi flap for a mangled lower extremity.

\section{Case Report}

A previously healthy 32-year-old female suffered from mangled bilateral lower extremities post motor vehicle accident. Her injuries included a left open midshaft comminuted femur fracture with an extensive degloving injury. This was treated acutely by the orthopedic surgery service with intramedullary nailing and serial debridement of the devitalized tissues. Our plastic surgery service was consulted three weeks after the accident for coverage of the exposed knee joint and part of the intramedullary nail.

The distal femur was covered with a medial transposition of the partially intact gracilis and vastus lateralis muscles. These muscles were not disinserted but were simply advanced. The knee was covered with a medial gastrocnemius muscle flap. The mid-thigh soft tissues required further debridement, resulting in more than a $75 \%$ loss of the quadriceps femoris muscle, leaving only the quadriceps tendon and a proximal muscle stump. This was in the context of an exposed fractured femur.

The functional level of the knee joint was minimal prior to reconstruction (approximately 5 degrees of active extension). Six weeks post-injury, our team elected to do a free latissimus dorsi flap for simultaneous soft tissue coverage and reconstruction of the quadriceps femoris muscle. The flap was anastomosed to the lateral circumflex femoral artery and vein. The thoracodorsal nerve was coapted to a branch of the femoral nerve that innervated the vastus lateralis. The resting length of the muscle was respected when inserted between the proximal thigh muscle and the quadriceps tendon to optimize contractibility. The muscle length was designed on the back prior to flap elevation based on the defect size. A split thickness skin graft was applied onto the muscle. A posterior slab was used to keep the knee in extension and to protect the repair. The patient's postoperative course was complicated by femoral shaft infection and bone loss, which were treated with intravenous antibiotics and tricortical bone grafting of the femoral shaft.

Eight months after the initial injury, the patient's latissimus dorsi flap electromyographic studies demonstrated active voluntary motor potential without evidence of denervation. The patient had a passive range of motion (ROM) of 80 degrees with a 55-degree extensor lag. The patient was able to ambulate with a cane and had regained partial extension of the left knee with an active flexion-extension range of 25 degrees (Medical Research Council Grade 3). The lack of full knee extension was in part due to an extremely stiff knee joint, which makes the postoperative extension obtained after the muscle transfer even more impressive (Video 1).

\section{Discussion}

Considered as one of the most versatile flaps, the advantages of free innervated latissimus dorsi flap have been shown in an impressive number of different integration sites, including upper limb, facial reanimation, scalp, abdominal wall reconstruction, bladder reconstruction, and dynamic cardiac myoplasty (2-7). In lower limb reconstructions, the free latissimus dorsi flap has been successfully used in patients with comorbidities such as diabetes, peripheral vascular diseases, and infections (8). As an innervated functional flap, its success is more thoroughly documented for immediate reconstruction post oncologic resection (8).

In trauma literature, the free latissimus dorsi flap has been traditionally used for challenging soft tissue reconstructions; preserving length in amputation of the lower extremities, lower limb reimplantation, and revascularization (9). We performed a thorough literature review of French and English articles through Pubmed and Ovid, using the term "latissimus dorsi flap" and cross-referencing methodology. This revealed only two cases describing the use of latissimus dorsi muscle flap as an innervated flap for functional reconstruction of the lower extremity trauma (Table 1). The first case presented a 16-year-old female who suffered a subtotal amputation of her left thigh. A neurotized latissimus dorsi was transferred acutely to replace the loss of the quadriceps muscle (10). A ten-year postoperative follow-up revealed excellent motor functions of the flap with electromyographic studies confirming no sign of denervation. The second case reported a 25-year-old male who suffered a gunshot injury to his thigh (11). A free latissimus dorsi flap was used for acute reconstruction of his quadriceps femoris. At eight months post reconstruction, the flap showed partial recruitment and the patient was able to perform full active knee extension. Our patient presented nine years after the last reported case of lower limb acute trauma reconstruction with innervated latissimus dorsi. Our literature review revealed scarce data on the use of 
Table 1. Review of the literature presenting all the cases of lower limb reconstruction with a functional latissimus dorsi in trauma.

\begin{tabular}{|c|c|c|c|c|c|c|}
\hline Reference & Patient & Etiology & $\begin{array}{l}\text { Repair } \\
\text { timing }\end{array}$ & Muscle replaced & $\begin{array}{l}\text { Recipient } \\
\text { nerve } \\
\end{array}$ & Result \\
\hline $\begin{array}{l}\text { Fanza } \\
1997[9]\end{array}$ & $\begin{array}{l}16 \text { year } \\
\text { old } \\
\text { female }\end{array}$ & $\mathrm{MVA}^{*}$ & $\begin{array}{l}\text { Acute } \\
\text { ( } 2 \text { days) }\end{array}$ & $\begin{array}{l}\text { Quadriceps } \\
\text { femoris loss, } \\
\text { femur fracture, } \\
\text { exposed knee }\end{array}$ & $\begin{array}{l}\text { Femoral nerve } \\
\text { branch }\end{array}$ & $\begin{array}{l}\text { Ambulation } \\
\text { without aid at } 1 \\
\text { year post-op }\end{array}$ \\
\hline $\begin{array}{l}\text { Hallock } \\
2004[10]\end{array}$ & $\begin{array}{l}25 \text { year } \\
\text { old male }\end{array}$ & $\mathrm{GSW}^{*}$ & $\begin{array}{l}\text { Acute } \\
\text { (7 days) }\end{array}$ & $\begin{array}{l}\text { Quadriceps } \\
\text { femoris loss }\end{array}$ & $\begin{array}{l}\text { Femoral nerve } \\
\text { branch }\end{array}$ & $\begin{array}{l}\text { Ambulation } \\
\text { without aids at } 6 \\
\text { months }\end{array}$ \\
\hline $\begin{array}{l}\text { Our case } \\
2016\end{array}$ & $\begin{array}{l}32 \text { year } \\
\text { old } \\
\text { female }\end{array}$ & $\mathrm{MVA}^{*}$ & $\begin{array}{l}\text { Subacute } \\
\text { (6 weeks) }\end{array}$ & $\begin{array}{l}\text { Quadriceps } \\
\text { femoris loss, } \\
\text { femur fracture, } \\
\text { exposed knee }\end{array}$ & $\begin{array}{l}\text { Femoral nerve } \\
\text { branch }\end{array}$ & $\begin{array}{l}\text { Ambulation with } \\
\text { aid at } 8 \text { months }\end{array}$ \\
\hline
\end{tabular}

${ }^{\bar{M}} \mathrm{MVA}=$ Motor Vehicle Accident, GSW = Gun Shot Wound

functional latissimus dorsi flap in trauma patients. In fact, this is the first case of subacute lower limb trauma reconstruction with a functional latissimus dorsi. Although it is still early in her post-operative course, the electromyographic studies of our patient's transferred latissimus dorsi as well as her clinical progression showed signs of re-innervation and functional integration of the latissimus dorsi in this atypical site. This case, alongside those found in the literature, confirm the incredible potential of latissimus dorsi not only for soft tissue coverage but also for functional lower limb reconstruction.

Although the latissimus dorsi has multiple inherent advantages as a functional free flap, its donor site also has morbidities, such as unsightly scars and high seroma rate. Alternatives can include the rectus femoris or tensor fascia lata, however, this would not have been possible in our patient, as both lower extremities suffered extensive trauma. In addition, in patients with lower extremity trauma, the latissimus dorsi donor site is far from the zone of injury and does not compromise the contralateral leg. This avoids further impediment to their ambulation rehabilitation.

\section{Conclusion}

This case report is the first case in the literature to date describing a subacute reconstruction with a functional latissimus dorsi in lower extremity trauma. Postoperative results illustrate that the free latissimus dorsi flap is not only a good option for soft tissue coverage, but also for functional muscle reconstruction post traumatic injury, even in a subacute context. This incredible potential should be used to its best capacities to improve reconstruction in trauma patients.

\section{References}

1. Gottlieb LJ, Krieger LM. From the Reconstructive Ladder to the Reconstructive Elevator. Plastic and reconstructive surgery 1994;93(7):1503.

2. Doi K, Sakai K, Ihara K, Abe Y, Kawai S, Kurafuji Y. Reinnervated free muscle transplantation for extremity reconstruction. Plastic and reconstructive surgery 1993;91(5):872-883.

3. Biglioli F, Colombo V, Tarabbia F, Autelitano L, Rabbiosi D, Coletti G, et al. Recovery of emotional smiling function in free-flap facial reanimation. Journal of Oral Maxillofac Surg 2012;70(10):2413-2418.

4. Ninkovic M, Kronberger P, Harpf C, Rumer A, Anderl $H$. Free innervated latissimus dorsi muscle flap for reconstruction of full-thickness abdominal wall defects. Plastic and reconstructive surgery 1998;101(4):971978.

5. Ninkovic M, Stenzl A, Hess $M$, Feichtinger $H$, Schwabegger A, Colleselli K, et al. Functional urinary bladder wall substitute using a free innervated latissimus dorsi muscle flap. Plastic and reconstructive surgery 1997;100(2):402-411

6. Grandjean P, Acker M, Madoff R, Williams NS, Woloszko J, Kantor C. Dynamic myoplasty: surgical transfer and stimulation of skeletal muscle for functional substitution or enhancement. Journal of rehabilitation research and development 1996;33(2):133-144.

7. Weitgasser L, Valina SW, Schoeller T, Ehebruster G. Herpes Zoster Lesions on Reconstructed Breast Skin: Rare Objective Proof of Reinervation. Arch Plast Surg. 2017 Jan;44(1):72-75.

8. Gooden MA, Gentile AT, Mills JL, Berman SS, Demas $\mathrm{CP}$, Reinke KR, et al. Free tissue transfer to extend the limits of limb salvage for lower extremity tissue 
loss. American journal of surgery 1997;174(6):644-

648.

9. Grinsell D, Di Bella C, Choong PF. Functional reconstruction of sarcoma defects utilising innervated free flaps. Sarcoma 2012;2012:315190.

10. Fansa H, Plogmeier K, Feistner H, Schneider WJ.

Plasticity and function--the fate of a free, neurovascular muscle graft ten years postreconstruction. Journal of reconstructive microsurgery 1997;13(8):551-554.

11. Hallock GG. Restoration of quadriceps femoris function with a dynamic microsurgical free latissimus dorsi muscle transfer. Annals of plastic surgery 2004;52(1):89-92. 